See discussions, stats, and author profiles for this publication at:

https://www.researchgate.net/publication/12908880

\title{
Caloric stimulation of ampullar receptors: A new method to produce mechanically- evoked responses in frog semicircular canals
}

Article in Journal of Neuroscience Methods · June 1999

Impact Factor: 2.05 · DOI: 10.1016/S0165-0270(99)00021-7 · Source: PubMed

CITATIONS

3

7 authors, including:

Laura Botta

University of Pavia

40 PUBLICATIONS 389 CITATIONS

SEE PROFILE

\section{Paola Perin}

University of Pavia

46 PUBLICATIONS 517 CITATIONS

SEE PROFILE
READS

23

\section{Beatrice Giannoni}

University of Florence

12 PUBLICATIONS 168 CITATIONS

SEE PROFILE

\section{Paolo Valli}

University of Pavia

77 PUBLICATIONS 1,180 CITATIONS

SEE PROFILE 


\title{
Caloric stimulation of ampullar receptors: a new method to produce mechanically-evoked responses in frog semicircular canals
}

\author{
G. Zucca ${ }^{\text {a }}$, L. Botta ${ }^{\text {a, }}$ S. Valli ${ }^{\text {b }}$, B. Giannoni ${ }^{\text {c }}$, E. Mira ${ }^{\text {b }}$, P. Perin ${ }^{\text {a }}$, P. Valli ${ }^{\text {a,* }}$ \\ a Institute of General Physiology, University of Pavia, Via Forlanini 6, I27100 Pavia, Italy \\ ${ }^{\mathrm{b}}$ Department of Otolaryngology and IRCCS Policlinico S. Matteo, University of Pavia, Pavia, Italy \\ ' Service of Audiology, University of Florence, Florence, Italy
}

Received 26 June 1998; received in revised form 11 January 1999; accepted 25 January 1999

\begin{abstract}
A microthermistor positioned close to the exposed posterior semicircular canal in isolated labyrinth preparations of the frog was used to stimulate the sensory organ. Our results indicated that, depending on the position of the heater, the induced endolymphatic convection currents may result in either excitatory or inhibitory cupular deflections and thus in a modulation of ampullar receptor resting activity. Other possible thermal-dependent mechanisms, such as a direct action of the stimulus on vestibular sensors or endolymphatic volume changes, had, in the present experimental conditions, a minor role. Caloric stimulation could therefore represent a novel method to stimulate the semicircular canals 'in situ'. (C) 1999 Elsevier Science B.V. All rights reserved.
\end{abstract}

Keywords: Frog; Vestibular receptors; Semicircular canal; Caloric stimulation; Thermoconvective currents

\section{Introduction}

According to thermoconvective theory first proposed by Barany (1906), the irrigation of the external ear canal with cool or warm water produces a gravity-dependent transcupular pressure difference, resulting in utriculofugal or utriculopetal deflections of the lateral semicircular canal cupula, which, by modifying ampullar receptor activity (see Kandel et al., 1994 and Guth et al., 1998 for a review), induce the well-known caloric nystagmus. Caloric tests are normally used to validate a diagnosis of asymmetric functioning of vestibular system (Jacobson et al., 1993).

The goal of the present study is to describe and present a method to generate controlled thermally-induced cupular deflections and, therefore, controlled responses of ampullar receptors to caloric stimuli.

\footnotetext{
* Corresponding author. Tel.: + 39-382-507608; fax: + 39-382507527.

E-mail address: paovalli@unipv.it (P. Valli)
}

This kind of stimulation could allow not only the activation 'in situ' of the semicircular canals but also substitute for other procedures of mechanical stimulation requiring more complex (by producing fluid flows inside the canal; Valli and Zucca, 1977; Valli et al., 1990) or expensive (by using turn-tables; Dickman and Correia, 1989; Rossi et al., 1994; Soto et al., 1994) machinery.

Convective currents, in the case of the caloric testing, are believed to be the main, but not the sole mode of activation of vestibular receptors. In fact, both a direct thermal action on vestibular sensory units and endolymphatic volume changes are claimed to play a role in receptor responses to caloric stimuli (Sherer and Clarke, 1985; Stahle, 1990; Gentine et al., 1990, 1991a,b,c). However, in the experimental conditions adopted in the present study, it can be demonstrated that the importance of these non-thermoconvective mechanisms is negligible and that ampullar receptors are mainly stimulated by thermically-induced transcupular pressure differences. 
The role of non-thermoconvective mechanisms might be an interesting starting point for a future study but is not in line with the aim of the present study.

\section{Materials and methods}

Experiments were carried out on whole labyrinth preparations isolated from frogs previously anaesthetized by immersion in $0.1 \% 3$-aminobenzoic acid ethyl ester methane sulfonate solution (MS-222, Sandoz).

After decapitation, the lower jaw was removed and the head cut in half. The bony temporal portion containing the right labyrinth was isolated by removing both the surrounding part of the skull and the brain stem. The otic capsule was opened and the posterior canal together with its ampullary nerve micro-dissected free. The preparation was then transferred into a $50 \mathrm{ml}$ perspex chamber filled with artificial perilymph (composition: $\mathrm{NaCl} 113 \mathrm{mM}$; $\mathrm{KCl} 2.5 \mathrm{mM}$; $\mathrm{NaHCO}_{3} 1.2$ $\mathrm{mM} ; \mathrm{NaH}_{2} \mathrm{PO}_{4} 0.17 \mathrm{mM} ; \mathrm{CaCl}_{2} 1.8 \mathrm{mM}$; glucose 5.5 $\mathrm{mM} ; \mathrm{pH}$ 7.3) and positioned at the center of the chamber so that the posterior canal lay in the vertical plane (Fig. 1). Multiunit nerve firing rate (Nfr), recorded from the posterior ampullar nerve by a suction electrode, was measured using a window discriminator and a frequency-to-voltage converter.

\subsection{Thermal stimulation of ampullar receptors}

\subsubsection{Thermal stimulation apparatus}

The apparatus for thermal stimulation of the frog labyrinth consisted of a heating probe (heater) and a current generator. The heater was built using a miniature NTC (negative temperature coefficient) resistor (diameter $1.5 \mathrm{~mm}$, length $5 \mathrm{~mm}$ ), sealed in a glass tube. The characteristics of the thermistor were:

Rbead $\left(25^{\circ} \mathrm{C}\right): 1000 \mathrm{ohm} \pm 20 \%$

Dissipation constant: $0.75 \mathrm{~mW} /{ }^{\circ} \mathrm{C}$

Thermal time constant: $5 \mathrm{~s}$

B constant: $2910 \mathrm{~K} \pm 3 \%$.

$\mathrm{R}$ bead indicates the nominal resistance of the resistor at $25^{\circ} \mathrm{C}$; the combination between the dissipation constant and time constant indicates the time required to reach thermal steady state conditions. For example, at $25^{\circ} \mathrm{C}$, a tension of $0.87 \mathrm{~V}$ applied to the thermistor will produce an increase of $1^{\circ} \mathrm{C}$ in $5 \mathrm{~s}$. B constant indicates the characteristic temperature constant $(\mathrm{K})$ of the resistor.

The heater was driven by a current generator controlled by a PC through its parallel port, and equipped with an in-house software program. Current intensity could be manually set within the range $0-20 \mathrm{~mA}$.

The personal computer allowed control, through an in-house QUICKBASIC program (V. 4.50), of the duration, lag and number of stimulus pulses (Appendix A). The program could drive two current generators, and therefore two heaters, at the same time. This allowed the experimenters to stimulate either different points of the same sensory organ or different sensory organs.

Fig. 2 illustrates the constant current generator. The current we used $(0-20 \mathrm{~mA})$ produced a power dissipation in the thermistor in the range $0-120 \mathrm{~mW}$, corresponding to a temperature increase of the liquid-bathed thermistor ranging from 0 to $65^{\circ} \mathrm{C}$.

Fig. 3 shows the liquid-bathed thermistor heating versus current intensity with $40 \mathrm{~s}$ long heating pulses

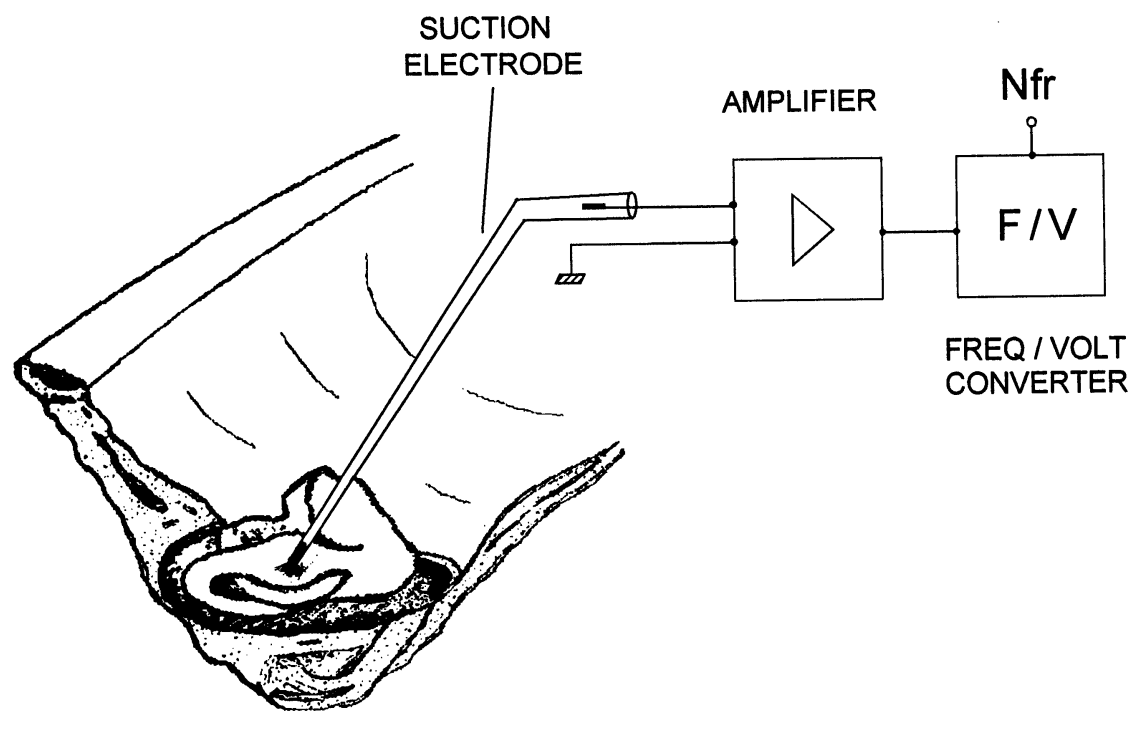

Fig. 1. Schematic representation of the experimental set-up for recording multiunit nerve firing rate (Nfr) from the ampullar nerve of the frog posterior canal. 


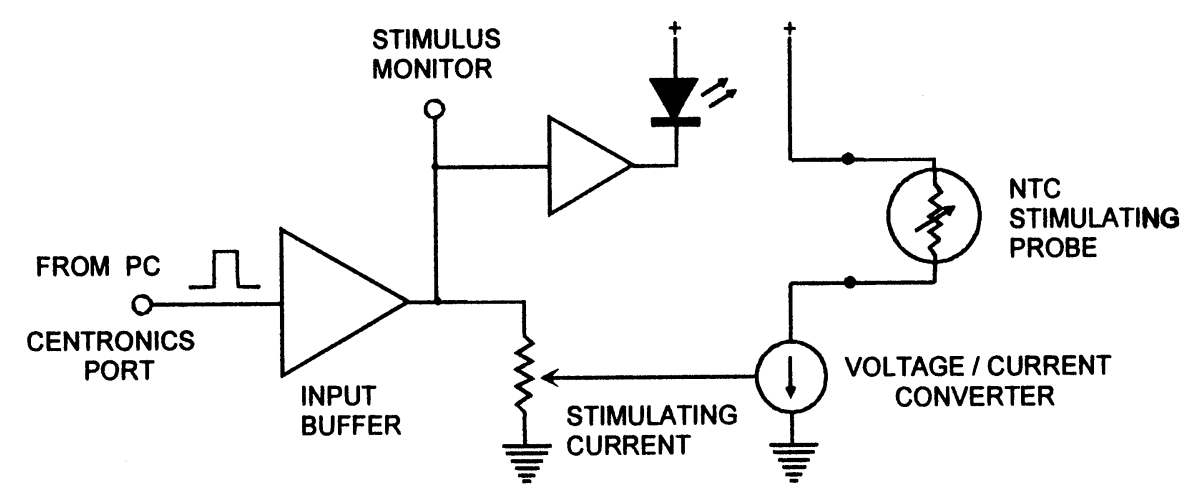

Fig. 2. Scheme of the electronic apparatus used to vary the current intensity across the microthermistor, and therefore the thermal stimulus intensity delivered to the ampullar receptors.

(more than sufficient to reach thermal equilibrium; Fig. 5). To evaluate the temperature increase of the liquid bathing the heater (and therefore of the semicircular canal wall) as a function of stimulus current we used a microthermometer, made by a second NTC thermistor, the mass of which and thermal time constant were much smaller than those of the stimulating thermistor.

For currents ranging from 0 to $20 \mathrm{~mA}$ and for a stimulus duration of $40 \mathrm{~s}$, the temperature increases in the liquid contacting the probe are displayed in Fig. 4. Fig. 5 shows the time course of the liquid temperature in response to a $14 \mathrm{~mA}$ current applied for $40 \mathrm{~s}$. It may be noted that a constant temperature is reached after about $5 \mathrm{~s}$ of current application.

We also measured the temperature changes in the bath at various distances from the heater, keeping current intensity and duration constant (14 mA, $40 \mathrm{~s})$. It may be seen (Fig. 6) that, by increasing the distance between the heater and the microthermometer, the temperature decreased in an exponential way. At about $1.6-1.8 \mathrm{~mm}$ from the heater no change in the liquid temperature could be detected.

A digital thermometer placed in the bath at a certain distance from the heather (more than $2 \mathrm{~mm}$ ) indicated that, in the present experimental conditions, no change in the bath temperature could be detected even after several hours of stimulation.

Regarding the arrangement of the preparation, the right half head of the frog was fixed at the center of the perspex chamber in such a way that the posterior canal lay in the vertical plane (Fig. 7). The heater was positioned, as a rule, at about $10 \mu \mathrm{m}$ from the canal wall, either in (B), i.e. close to the crus commune or in (A). Thus they were arranged symmetrically with regard to the ampulla of the posterior canal (see scheme in Fig. 7).

The present experiments were performed in accordance with the guidelines of the Declaration of Helsinki.

\section{Results}

As shown in Fig. 8, the firing rate of ampullar receptors was extremely sensitive to temperature changes in the fluid contacting the canal walls. Temperature changes as low as $0.08^{\circ} \mathrm{C}$ were sufficient to produce distinct changes in receptor resting discharge and responses saturated for temperature changes higher than $1^{\circ} \mathrm{C}$. It may be noted that when the heater was positioned in (B), i.e. close to the crus commune, a condition in which utriculofugal (excitatory) endolymphatic flows would be generated, a prompt increase in nerve firing rate (Nfr) was observed. Especially for the highest stimuli tested $\left(1-1.50^{\circ} \mathrm{C}\right)$, this $\mathrm{Nfr}$ enhancement soon decreased and, in about 30-40 $\mathrm{s}$, gave rise to an undershoot lasting $40-50 \mathrm{~s}$. At the removal of the excitatory stimulus the sensory discharge was inhibited and recovered its resting value in about 2 min.

When the heater was positioned in (A), i.e. in a position in which utriculopetal (inhibitory) flows were generated, the firing rate was clearly decreased and, for the highest stimuli tested, nearly zeroed for about $15-$ 20 s. Then Nfr slowly increased but without recovering its resting level within the stimulation period $(2 \mathrm{~min})$. At the removal of the inhibitory stimulus, a rebound discharge was observed, the intensity and duration of which were dependent on stimulus strength.

Fig. 9 refers to an experiment in which a saturating excitatory stimulus $\left(10 \mathrm{~mA}, 1.10^{\circ} \mathrm{C}\right)$ was applied every $15 \mathrm{~min}$ to the same preparation over a period of $8 \mathrm{~h}$. It may be seen that only slight changes in both resting and thermally-evoked activity could be detected as a function of survival time. This indicates that this kind of stimulation is well-tolerated by the sensory organ.

The results described in Fig. 8 clearly demonstrate that, according to the position of the heater, it is possible to obtain both excitatory or inhibitory responses of ampullar receptors. It follows that by employing two heaters, one located in (A) and the other in 
(B), and a suitable program of stimulation where the stimulus of one heater is delayed with respect to the other, it is possible to obtain a succession of excitatory and inhibitory cupular deflections and therefore 'sinusoidal-like' responses of ampullar receptors to caloric stimuli (Fig. 10).

\section{Discussion}

The findings of the present study clearly demonstrate that ampullar receptors can be thermally stimulated (activated or inhibited) by means of microheaters placed in the vicinity of the sensory organ. The results referred to experiments carried out on posterior semicircular canals but, with suitable microdissection and positioning of the heater, anterior and lateral canals can be thermally stimulated as well (data not shown).

The experiments have also shown that this kind of stimulation is perfectly tolerated by the preparation. In fact ampullar receptors could respond to thermal stimuli with constant and repeatable responses for $8 \mathrm{~h}$.

Caloric stimulation of semicircular canals therefore can be usefully employed to induce mechanicallyevoked responses of ampullar receptors and, if particular patterns of stimulation are not required, can replace other methods of stimulation which may be more complicated, damaging or expensive. This method might be particularly suitable in experiments in which intracellular recordings from single fibres are required. In fact, during caloric stimulation of ampullar receptors, no movements of the preparation are produced and this greatly facilitates the maintaining of the impalement for a longer time.

Regarding the mechanism of hair cell activation, our results suggest that thermoconvective endolymphatic currents (producing steady transcupular pressure differences and, therefore, steady cupular deflections) are involved. Other possible mechanisms such as a direct effect of the temperature on vestibular sensors (Zucca et al., 1983a,b; Rossi et al., 1995; Zenner and Zimmermann, 1995) or endolymphatic volume changes (Gentine et al., 1991b) play, if any, a minor role. In fact the heater was placed about $2 \mathrm{~mm}$ from the sensory epithelium (Fig. 7). At this distance, even the highest stimulus tested was unable to produce measurable thermal changes at the level of the ampulla (Fig. 6).

Regarding the importance of the expansion of the endolymph, it may be calculated that, within the range tested $\left(\Delta T=0-1.5^{\circ} \mathrm{C}\right)$, the highest hydrostatic pressure generated by this mechanism (Gentine et al., 1991b) is about $10^{-1} \mathrm{~Pa}$. In a previous study we demonstrated that hydrostatic pressure differences of at least 0.25 $\mathrm{mmH}_{2} \mathrm{O}$ between the endolymph and the perilymph (about $2.5 \mathrm{~Pa}$ ) are needed to affect the activity of vestibular sensors (Zucca et al., 1991). This pressure therefore is about 25 times lower than that needed to modify ampullar receptor activity.

The hypothesis that the main effect of thermal stimuli was to produce transcupular pressure differences is further supported by the fact that the time course of thermally-evoked responses was very similar to that observed in isolated semicircular canals after application of step mechanical stimuli of the same duration (Zucca et al., 1993).

\section{Appendix A. Listing of the program}

'Main Program "ESE5A.BAS”,

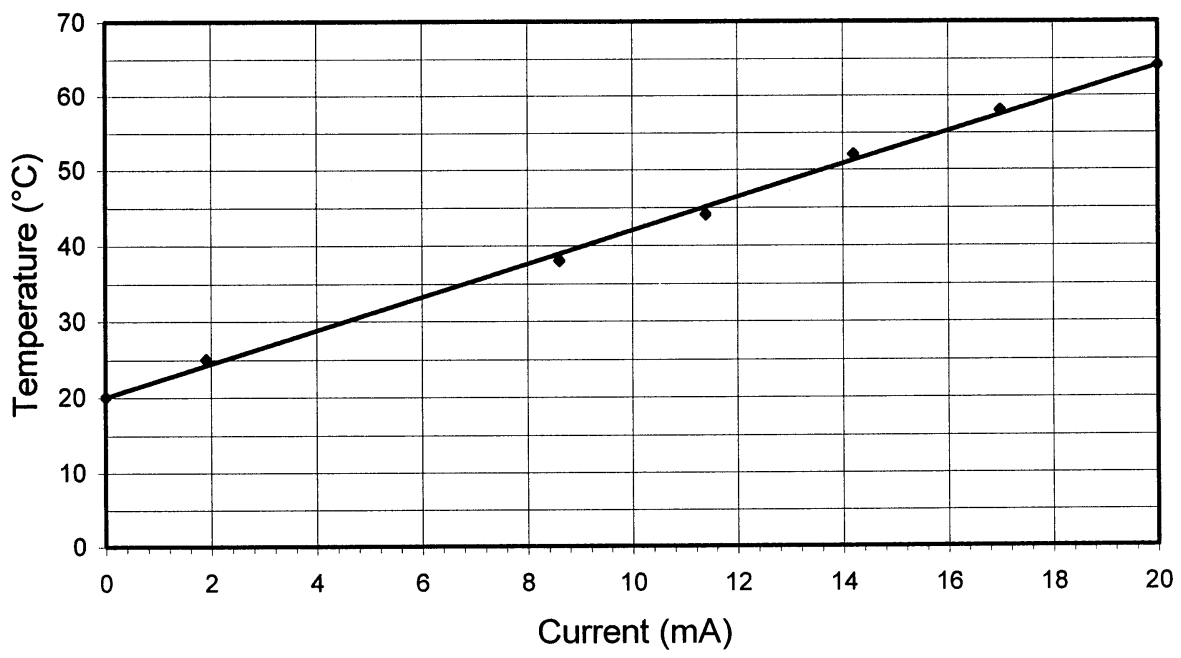

Fig. 3. Relation between the current across the thermistor and the temperature of the thermistor itself. The experimental points used to calculate the regression curve were obtained using the thermistor temperature-resistance relation, given by the builder of the microthermistor itself. The relation is described by the straight line of equation: $y=2.2013 x+20.012\left(R^{2}=0.9978\right)$. 


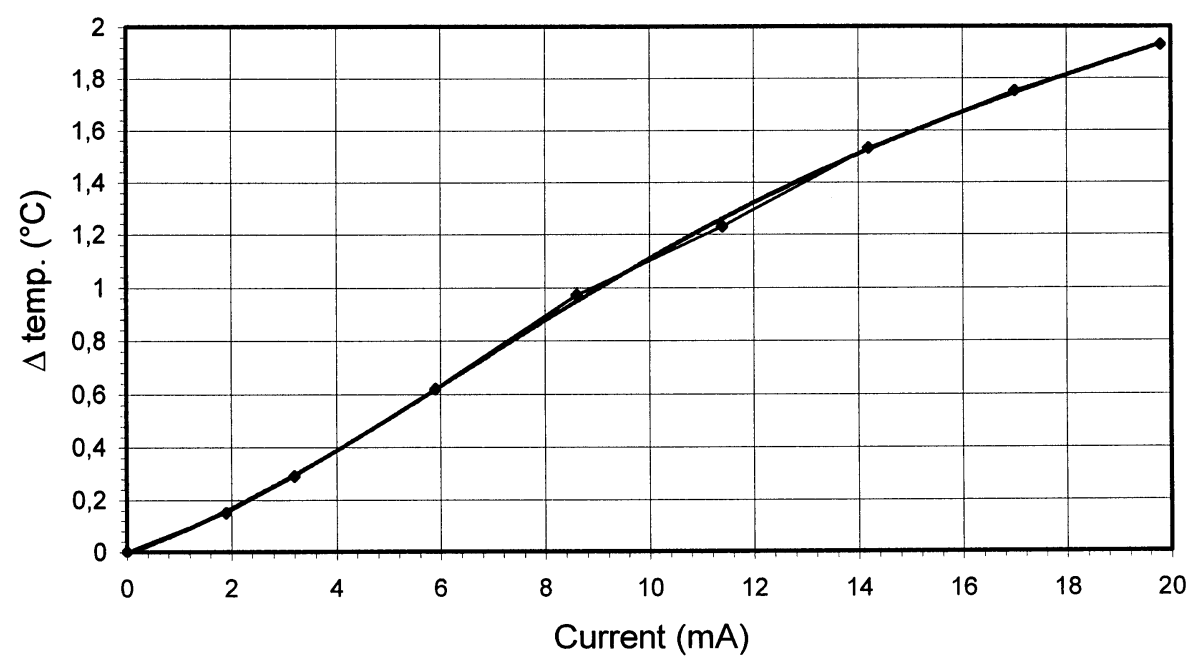

Fig. 4. Relation between the current across the thermistor and temperature changes $(\Delta T)$ in the fluid bathing the heater. The experimental points used to obtain the regression curve were measured by means of a microthermometer positioned about $10 \mu \mathrm{m}$ from the heater. The relation is described by the equation: $y=0.003 x^{4}-0.0082 x^{3}+0.0557 x^{2}+0.1826 x-0.2325\left(R^{2}=0.9997\right)$.

DECLARE SUB contemp ()

DECLARE SUB dopinv ()

DECLARE SUB Inibitorio ()

DECLARE SUB eccitatorio ()

DECLARE SUB doppio ()

SCREEN 0

OUT 888,0

menu:

CLS

LOCATE 2， 5: PRINT CHR\$(201);: $\quad$ PRINT STRING\$(70, 205);: PRINT CHR\$(187);

FOR $x=3$ TO 20

LOCATE $x, 5$ : PRINT CHR\$(186);: LOCATE $x, 76$ :

PRINT CHR\$(186);

NEXT $x$

LOCATE 21， 5: PRINT CHR\$(200);: $\quad$ PRINT STRING\$(70, 205);: PRINT CHR\$(188);

LOCATE 5, 25: COLOR 0, 7: PRINT "LABYRINTH THERMAL STIMULATION";:

COLOR 7, 0

LOCATE 7, 15: COLOR 15: PRINT “1”;: COLOR

7: PRINT "-Excitatory stimulus $\uparrow \uparrow \uparrow "$

LOCATE 9, 15: COLOR 15: PRINT “2”;: COLOR

7: PRINT “-Inhibitory stimulus $\downarrow \downarrow \downarrow)$

LOCATE 11, 15: COLOR 15: PRINT “3”;: COLOR

7: PRINT “-Excitatory + inhibitory stimuli $\uparrow \downarrow \uparrow \downarrow$ ”

LOCATE 13, 15: COLOR 15: PRINT “4”;: COLOR

7: PRINT “-Inhibitory + excitatory stimuli $\downarrow \uparrow \downarrow \uparrow "$

LOCATE 15, 15: COLOR 15: PRINT “5”;: COLOR

7: PRINT "-Simultaneous stimuli $\phi \phi \phi \phi$ "

LOCATE 17, 15: COLOR 15: PRINT “6”;: COLOR

7: PRINT "-Exit"

LOCATE 19, 40: INPUT "Stimulus?"; sc\%

SELECT CASE $\mathrm{sc} \%$
CASE 1: CALL eccitatorio

CASE 2: CALL Inibitorio

CASE 3: CALL doppio

CASE 4: CALL dopinv

CASE 5: CALL contemp

CASE 6: CLS: END

CASE ELSE: PRINT: PRINT "print a number (16)"

END SELECT
GOTO menu
END

SUB contemp

DEFINT A-M

parcon:

CLS

LOCATE 2, 24: COLOR 0, 7: PRINT "SIMULTANEOUS STIMULI': COLOR 7, 0

LOCATE 4, 10

INPUT "Stimulus duration (sec)"; ds1

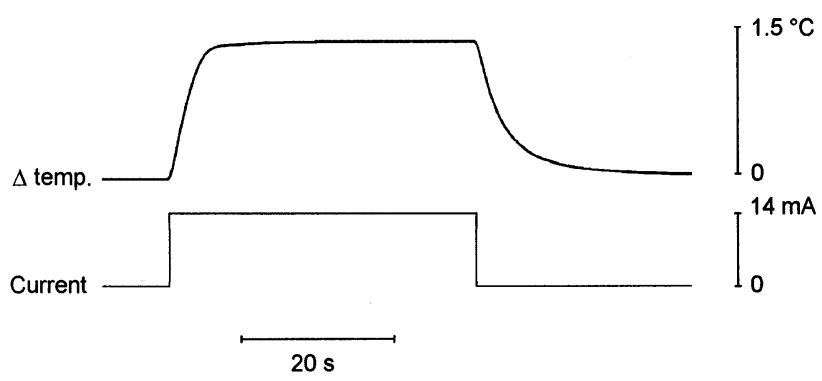

Fig. 5. Comparison between the time course of the current across the heater and the temperature changes $(\Delta T)$ in the surrounding fluid. 


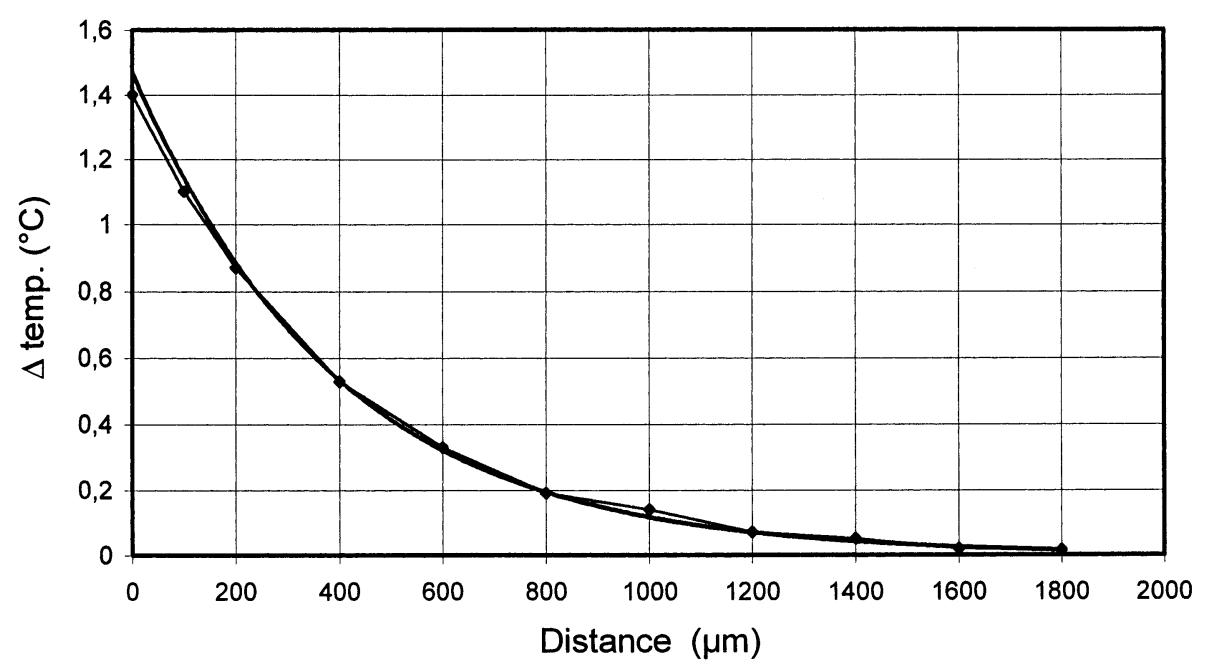

Fig. 6. Temperature changes $(\Delta T)$ at increasing distances from the heater. Stimulus parameters: $14 \mathrm{~mA} ; 40 \mathrm{~s}$. The curve fitting the experimental points was described by the exponential equation: $y=1.47 e^{-0.0025 x}\left(R^{2}=0.995\right)$.

LOCATE 6, 10

INPUT “Cycles' number”; nc

LOCATE 8,10

INPUT "Delay between two stimuli (sec)"; rs1

LOCATE 10, 30: COLOR 27, 0: PRINT "for stimulation...";: COLOR 7, 0

LOCATE 25, 5: PRINT " $<$ ESC $>$ to change datamain menu";

tasti:

$\mathrm{kbd} \$=$ INKEY $\$$

IF $\mathrm{kbd} \$=$ ",'THEN GOTO tasti

IF $\mathrm{kbd} \$=\mathrm{CHR} \$(0)+\mathrm{CHR} \$(68)$ THEN GOTO

incont

IF $\mathrm{kbd} \$=\mathrm{CHR} \$(27)$ THEN GOTO parcon

IF $\mathrm{kbd} \$=\mathrm{CHR} \$(0)+\mathrm{CHR} \$(59)$ THEN GOTO

fin

GOTO tasti

END

incont:

LOCATE 10, 30: COLOR 7, 0: PRINT"

LOCATE 12, 15: PRINT “-Start stimulation-"

FOR $b=1$ TO nc

PRINT "Stimulus"; b

tim1 = TIMER

$\operatorname{tim} 2=\operatorname{tim} 1+\mathrm{ds} 1$

OUT 888, 192

DO UNTIL TIMER $>=\operatorname{tim} 2$

LOOP

OUT 888,0

rit $1=$ TIMER

rit2 $=$ rit $1+$ rs 1

DO UNTIL TIMER $>=$ rit2

LOOP

NEXT b

PRINT “-End stimulation_-": PRINT

PRINT "for stimulation..."
LOCATE 25, 3: PRINT “main menu”;

opzio:

$\operatorname{kbd} \$=$ INKEY\$

IF $\mathrm{kbd} \$=$ ",'THEN GOTO opzio

IF $\mathrm{kbd} \$=\mathrm{CHR} \$(0)+\mathrm{CHR} \$(68)$ THEN GOTO parcon

IF $\mathrm{kbd} \$=\mathrm{CHR} \$(0)+\mathrm{CHR} \$(59)$ THEN GOTO fin

END

fin:

CLS

END SUB

DEFSNG A-M

SUB dopinv

DEFINT A-M

pardi:

CLS

LOCATE 2, 20: COLOR 0, 7: PRINT "INHIBITORY + EXCITATORY STIMULI": COLOR 7,0

LOCATE 5, 10

INPUT "Inhibitory stimulus duration (sec)"; di1

LOCATE 6, 10

INPUT "Excitatory stimulus duration (sec)"; de1

LOCATE 7, 10

INPUT “Cycles' number"; nc

LOCATE 8,10

INPUT "Delay after the inhibitory stimulus (sec)"; ril

LOCATE 9, 10

INPUT "Delay after the excitatory stimulus (sec)"; re1

LOCATE 10, 30: COLOR 27, 0: PRINT "for stimulation...";: COLOR 7, 0 
LOCATE 25, 5: PRINT “ $<$ ESC $>$ to change datamain menu";

tastt:

$\mathrm{kbd} \$=\mathrm{INKEY} \$$

IF kbd $\$="$, THEN GOTO tastt

IF $\mathrm{kbd} \$=\mathrm{CHR} \$(0)+\mathrm{CHR} \$(68)$ THEN GOTO

indi

IF $\mathrm{kbd} \$=\mathrm{CHR} \$(27)$ THEN GOTO pardi

IF $\mathrm{kbd} \$=\mathrm{CHR} \$(0)+\mathrm{CHR} \$(59)$ THEN GOTO

finn

GOTO tastt

END

indi:

LOCATE 10, 30: COLOR 7, 0: PRINT"”;

LOCATE 12, 15: PRINT "-Start stimulation-"

FOR $b=1$ TO nc

PRINT "Stimulus"; b

tim3 = TIMER

$\operatorname{tim} 4=\operatorname{tim} 3+\operatorname{di} 1$

OUT 888,64

DO UNTIL TIMER $>=\operatorname{tim} 4$

LOOP

OUT 888,0

rit $3=$ TIMER

rit4 $=$ rit3 + ri1

DO UNTIL TIMER $>=$ rit4

LOOP

tim1 $=$ TIMER

$\operatorname{tim} 2=\operatorname{tim} 1+$ de 1

OUT 888,128

DO UNTIL TIMER $>=\operatorname{tim} 2$

LOOP

OUT 888,0

rit1 $=$ TIMER

rit $2=$ rit $1+$ re 1

DO UNTIL TIMER $>=$ rit2
LOOP

NEXT $b$

PRINT “-End stimulation —": PRINT

PRINT "for stimulation"

LOCATE 25, 5: PRINT "main menu";

opzione:

$\mathrm{kbd} \$=\mathrm{INKEY} \$$

IF kbd $\$=$ "',THEN GOTO opzione

IF $\mathrm{kbd} \$=\mathrm{CHR} \$(0)+\mathrm{CHR} \$(68)$ THEN GOTO pardi

IF $\mathrm{kbd} \$=\mathrm{CHR} \$(0)+\mathrm{CHR} \$(59)$ THEN GOTO finn

END

finn:

CLS

END SUB

DEFSNG A-M

SUB doppio

DEFINT A-M

pardop:

CLS

LOCATE 2, 20: COLOR 0, 7: PRINT "EXCITATORY + INHIBITORY STIMULI": COLOR 7, 0 LOCATE 5, 10

INPUT "Excitatory stimulus duration (sec)"; de1 LOCATE 6, 10

INPUT "Inhibitory stimulus duration (sec)"; di1 LOCATE 7, 10

INPUT “Cycles' number”; nc

LOCATE 8, 10

INPUT "Delay after the excitatory stimulus (sec)"; re1

LOCATE 9, 10

INPUT "Delay after the inhibitory stimulus (sec)"; ri1
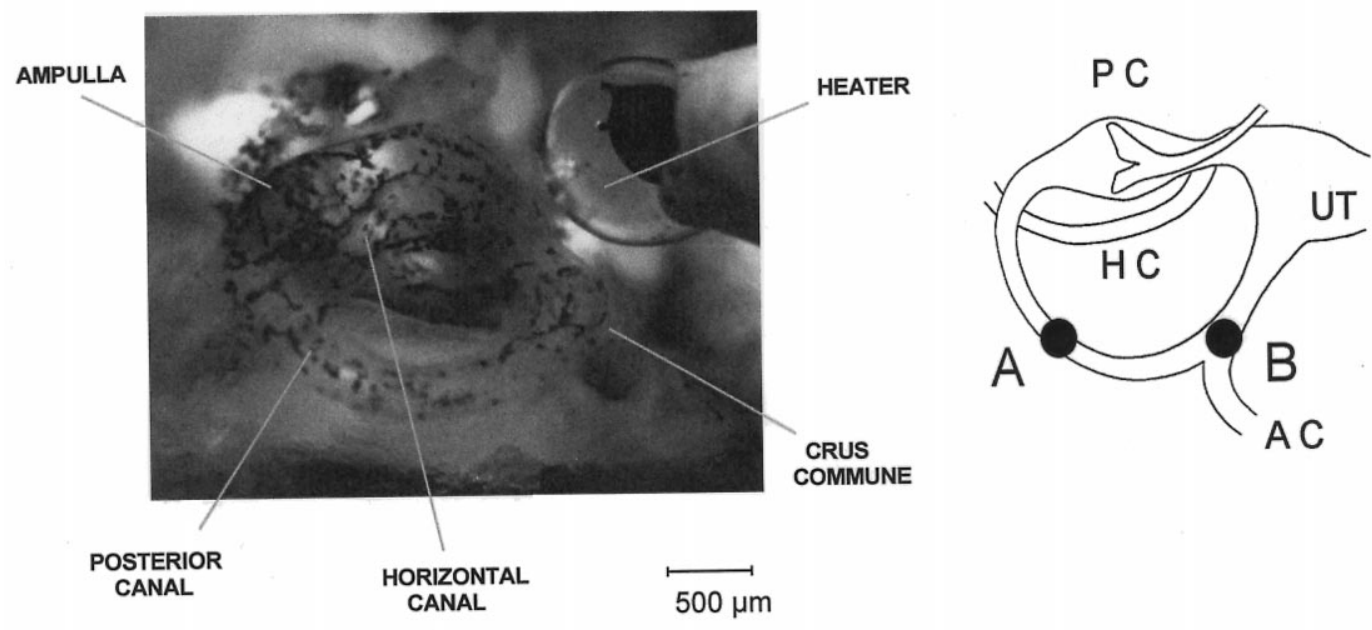

Fig. 7. Microphotography showing both the preparation and the heater which, as indicated by the inset, was usually placed in (A) or in (B) (see text). 

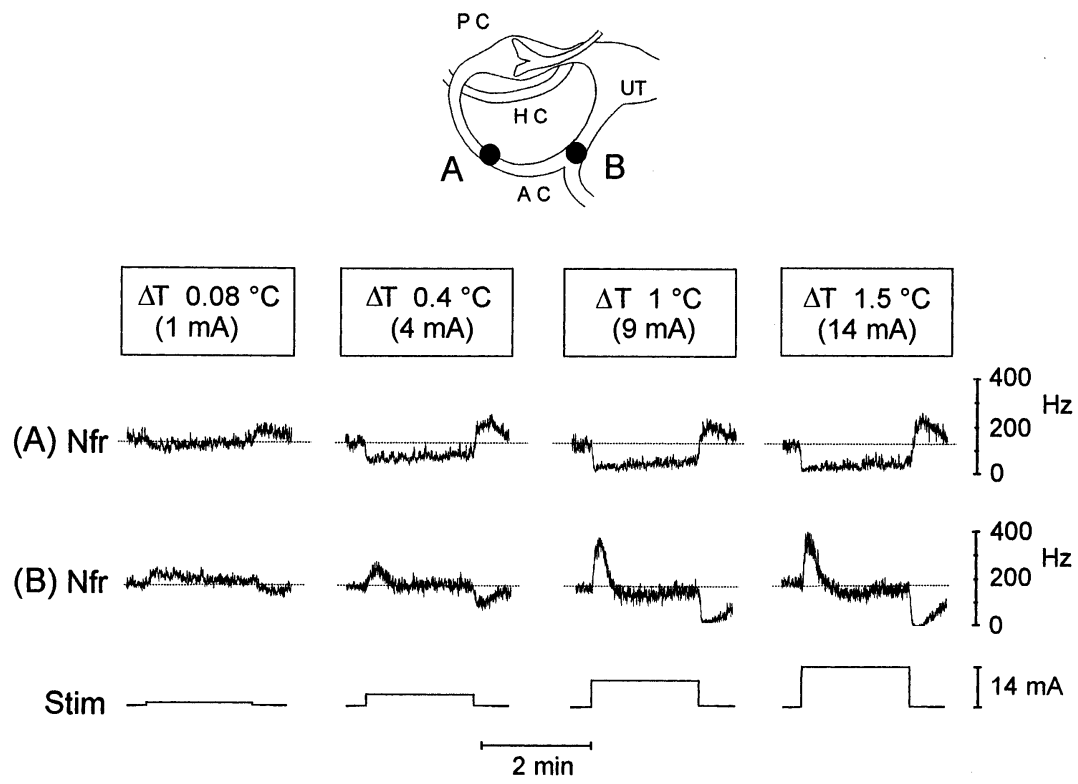

Fig. 8. Effects of thermal stimuli (14 mA; $2 \mathrm{~min})$ applied in (A) or in (B) on the firing rate (Nfr) recorded from the ampullary nerve of the posterior canal. Dotted lines indicate the level of the resting activity.

LOCATE 10, 30: COLOR 27, 0: PRINT "for stimulation...";: COLOR 7,0

LOCATE 25, 5: PRINT " $<$ ESC $>$ to change datamain menu";

tast:

$\mathrm{kbd} \$=\mathrm{INKEY} \$$

IF $\mathrm{kbd} \$=$ ",'THEN GOTO tast

IF $\mathrm{kbd} \$=\mathrm{CHR} \$(0)+\mathrm{CHR} \$(68)$ THEN GOTO indop

IF $\mathrm{kbd} \$=\mathrm{CHR} \$(27)$ THEN GOTO pardop

IF $\mathrm{kbd} \$=\mathrm{CHR} \$(0)+\mathrm{CHR} \$(59)$ THEN GOTO finee

GOTO tast

\section{END}

indop:

LOCATE 10, 30: COLOR 7, 0: PRINT “"”;

LOCATE 12, 15: PRINT “- Start stimulation-"

FOR $b=1$ TO nc

PRINT "Stimulus"; b

timl $=$ TIMER

$\operatorname{tim} 2=\operatorname{tim} 1+$ de 1

OUT 888, 128

DO UNTIL TIMER $>=\operatorname{tim} 2$

LOOP

OUT 888,0

rit $1=$ TIMER

rit2 $=$ rit $1+$ re 1

DO UNTIL TIMER $>=$ rit2

LOOP

tim3 = TIMER

$\operatorname{tim} 4=\operatorname{tim} 3+\operatorname{di} 1$

OUT 888,64
DO UNTIL TIMER $>=\operatorname{tim} 4$

LOOP

OUT 888,0

rit3 $=$ TIMER

rit4 $=$ rit3 + ri1

DO UNTIL TIMER $>=$ rit4

LOOP

NEXT b

PRINT “-End stimulation-": PRINT

PRINT "for stimulation..."

LOCATE 25, 5: PRINT "main menu";

opzi:

$\mathrm{kbd} \$=\mathrm{INKEY} \$$

IF kbd\$ $=$ "',THEN GOTO opzi

IF $\mathrm{kbd} \$=\mathrm{CHR} \$(0)+\mathrm{CHR} \$(68)$ THEN GOTO pardop

IF $\mathrm{kbd} \$=\mathrm{CHR} \$(0)+\mathrm{CHR} \$(59)$ THEN GOTO finee

END

finee:

CLS

END SUB

DEFSNG A-M

SUB eccitatorio

DEFINT A-M

parecc:

CLS

LOCATE 2, 24: COLOR 0, 7: PRINT "EXCITATORY STIMULUS": COLOR 7, 0

LOCATE 4, 10 
INPUT "Excitatory stimulus duration (sec)"; d1

LOCATE 6, 10

INPUT "Number of stimuli"; n1

LOCATE 8, 10

INPUT "Delay between stimuli (sec)"; r1

LOCATE 10, 30: COLOR 27, 0: PRINT "for stimulation...";: COLOR 7, 0

LOCATE 25, 5: PRINT “ $<$ ESC $>$ to change datamain menu";

tasto:

$\mathrm{kbd} \$=$ INKEY\$

IF $\mathrm{kbd} \$="$ "'THEN GOTO tasto

IF $\mathrm{kbd} \$=\mathrm{CHR} \$(0)+\mathrm{CHR} \$(68)$ THEN GOTO

inecc

IF $\mathrm{kbd} \$=\mathrm{CHR} \$(27)$ THEN GOTO parecc

IF $\mathrm{kbd} \$=\mathrm{CHR} \$(0)+\mathrm{CHR} \$(59)$ THEN GOTO

fine

GOTO tasto

\section{END}

inecc:

LOCATE 10, 30: COLOR 7, 0: PRINT “"”;

LOCATE 12, 15: PRINT "-Start stimulation-"

FOR $\mathrm{a}=1$ TO $\mathrm{n} 1$

PRINT "Stimulus"; a

tim1 $=$ TIMER

$\operatorname{tim} 2=\operatorname{tim} 1+\mathrm{d} 1$

OUT 888,128

DO UNTIL TIMER $>=\operatorname{tim} 2$

LOOP

OUT 888,0

rit1 $=$ TIMER

rit2 $=$ rit $1+\mathrm{r} 1$

DO UNTIL TIMER $>=$ rit2

LOOP

NEXT a

PRINT “-End stimulation_—”: PRINT
PRINT "for stimulation"

LOCATE 25, 3: PRINT "main menu";

scelta:

$\mathrm{kbd} \$=\mathrm{INKEY} \$$

IF kbd $\$=$ "',THEN GOTO scelta

IF $\mathrm{kbd} \$=\mathrm{CHR} \$(0)+\mathrm{CHR} \$(68)$ THEN GOTO parecc

IF $\mathrm{kbd} \$=\mathrm{CHR} \$(0)+\mathrm{CHR} \$(59)$ THEN GOTO fine

END

fine:

CLS

END SUB

DEFSNG A-M

SUB Inibitorio

DEFINT A-M

parin:

CLS

LOCATE 2, 24: COLOR 0, 7: PRINT "IN-

HIBITORY STIMULUS": COLOR 7, 0

LOCATE 4, 10

INPUT "Inhibitory stimulus duration (sec)"; d3

LOCATE 6, 10

INPUT "Number of stimuli"; n3

LOCATE 8, 10

INPUT "Delay between stimuli (sec)"; r3

LOCATE 10, 30: COLOR 27, 0: PRINT "for stimulation...";: COLOR 7, 0

LOCATE 25, 5: PRINT " $<$ ESC $>$ to change datamain menu";

tas:

$\mathrm{kbd} \$=\mathrm{INKEY} \$$

IF kbd $\$=$ "',THEN GOTO tas

IF $\mathrm{kbd} \$=\mathrm{CHR} \$(0)+\mathrm{CHR} \$(68)$ THEN GOTO inin
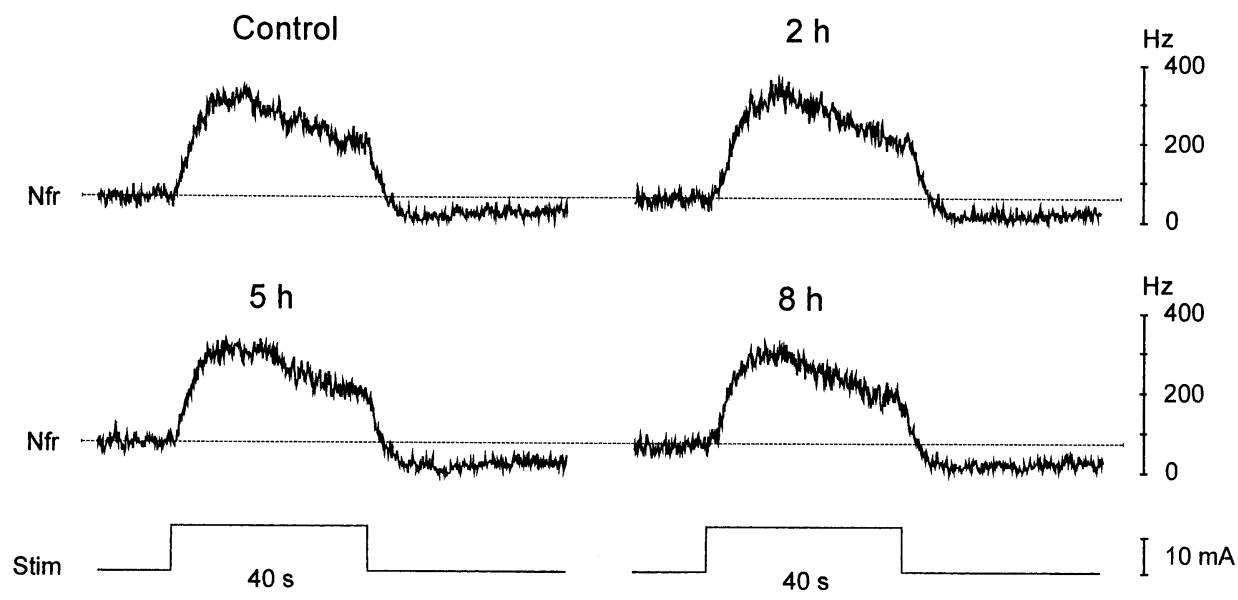

Fig. 9. Nerve firing rate (Nfr) recorded from the ampullar nerve as a function of time. The preparation was thermally stimulated (10 $\mathrm{mA}$; $40 \mathrm{~s})$ every $15 \mathrm{~min}$ over a period of $8 \mathrm{~h}$. Dotted lines indicate the level of the resting activity. 


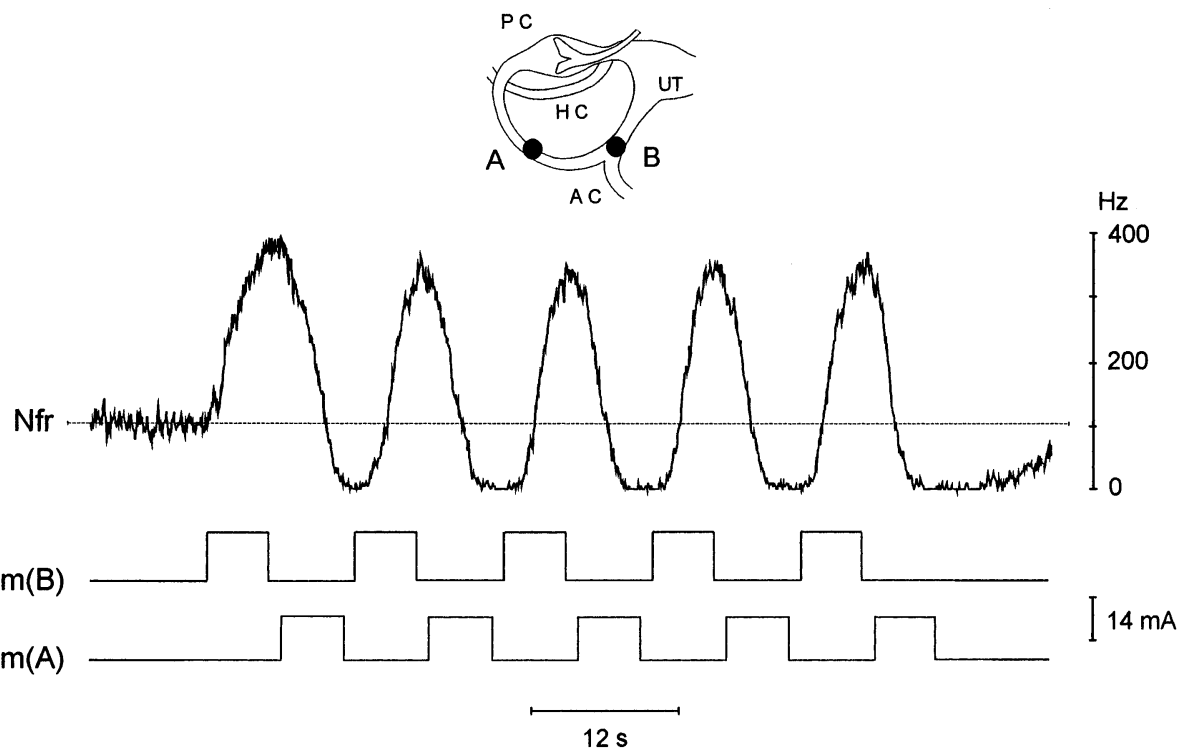

Fig. 10. Sinusoidal-like responses of ampullar receptors to suitable caloric stimuli applied alternatively in (B) and in (A). Dotted lines indicate the level of the resting activity.

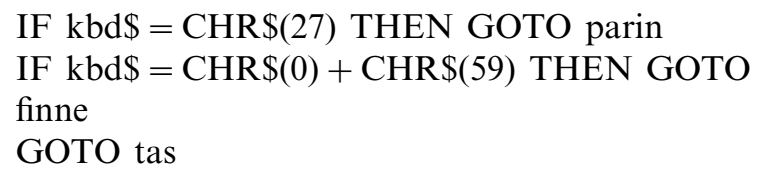

\section{References}

Barany R. Untersuchungen uber den vom Vestibulapparat des Ohres reflektorisch ausgelosten rhytmischen nystagmus und seine Begleiterscheinungen. Monatschr Ohrenlheilk (Berlin) 1906;40:193297.

Dickman JD, Correia JM. Response of pigeon horizontal semicircular canal afferent fibres. Step, trapezoid and low-frequency sinusoidal mechanical and rotational stimulation. J Neurophysiol 1989;62:1090-101.

Gentine A, Eichorn JL, Kopp C, Conraux C. Modelling the action of caloric stimulation of the vestibule. I: The hydrostatic model. Acta Otolaryngol (Stockh) 1990;110:328-33.

Gentine A, Eichorn JL, Kopp C, Conraux C. Modelling the action of caloric stimulation of the vestibule. II: The mechanical model of the semicircular canal considered as an inflatable structure. Acta Otolaryngol (Stockh) 1991a;111:10-5.

Gentine A, Eichorn JL, Kopp C, Conraux C. Modelling the action of caloric stimulation of the vestibule. III: Caloric nystagmus induced by osmotic pressure variations. Acta Otolaryngol (Stockh) 1991b;111:463-7.

Gentine A, Eichorn JL, Kopp C, Conraux C. Modelling the action of caloric stimulation of the vestibule. IV: The global mechanical model. Acta Otolaryngol (Stockh) 1991c;111:633-8.

Guth PS, Perin P, Norris CH, Valli P. The vestibular hair cells: post-transductional signal processing. Prog Neurobiol 1998; 54:193-247.

Jacobson GP, Newman CW, Peterson EL. Interpretation and usefulness of caloric testing. In: Jacobson, Newman, Kartush, editors. Handbook of Balance Function Testing. St Louis, MO: Mosby Year Book, 1993:192.

Kandel E.R., Schwartz J.H., Jessell, M.T. The sense of balance. In: Principles of Neural Science, 3rd edn., 1994:501-511.

Rossi ML, Martini M, Pelucchi B, Fesce R. Quantal nature of synaptic transmission at the cytoneural junction in the frog labyrinth. J Physiol (Lond) 1994;478:17-35.

Rossi ML, Martini M, Pelucchi B, Fesce R. Pre- and postsynaptic effects of temperature at the posterior canal cytoneural junctions in the isolated frog labyrinth. Prim Sensory Neuron 1995;1:95108. 
Sherer H, Clarke AH. The caloric vestibular reaction in space. Acta Otolaryngol (Stockh) 1985;100:328-36.

Soto E, Flores A, Eróstegui C, Vega R. Evidence for NMDA receptor in the afferent synaptic transmission of the vestibular system. Brain Res 1994;633:289-96.

Stahle J. Controversies on the caloric response. From Barany's Theory to studies in microgravity. Acta Otolaryngol (Stockh) 1990;109:162-7.

Valli P, Zucca G. The importance of potassium in the function of frog semicircular canals. Acta Otolaryngol (Stockh) 1977;84:34451.

Valli P, Zucca G, Botta L. Perilymphatic potassium changes and potassium homeostasis in isolated semicircular canals of the frog. J Physiol (Lond) 1990;430:585-94.
Zenner HP, Zimmermann U. Caloric evoked motile responses of mammalian vestibular sensory cells. Acta Otolaryngol (Stockh) 1995;115:484-7.

Zucca G, Valli P, Botta L, Casella C. Dipendenza termica dei potenziali elettrici nei canali semicircolari della rana. Boll Soc It Biol Sper 1983a;59:1016-22.

Zucca G, Valli P, Botta L, Casella C. Effetti della temperatura sui potenziali postsinaptici nelle giunzioni citoneurali dei canali semicircolari della rana. Boll Soc It Biol Sper 1983b;59:1010-5.

Zucca G, Botta L, Mira E, Manfrin, Poletti A, Buizza A, Valli P. Effects of hydrostatic pressure on sensory discharge in frog semicircular canals. Acta Otolaryngol (Stockh) 1991;111:820-6.

Zucca G, Botta L, Milesi V, Valli P. Sensory adaptation in frog vestibular organs. Hear Res 1993;63:52-6. 